\title{
PENGEMBANGAN BUKU SUPLEMEN MEMBACA UNTUK MENDUKUNG PELAKSANAAN METODE TRIFOKUS GUNA MENINGKATKAN KECEPATAN EFEKTIF MEMBACA (KEM) SISWA KELAS IV SD
}

\author{
${ }^{1}$ Bayu Endah Lestari, ${ }^{2}$ Kisyani Laksono, ${ }^{3}$ Suhartono \\ ${ }^{1}$ Mahasiswa Program Pascasarjana, Prodi Pendidikan Dasar, Universitas Negeri Surabaya, \\ ${ }^{2 \& 3}$ Dosen Pascasarjana, Prodi Pendidikan Dasar, Universitas Negeri Surabaya \\ e-mail: bayuendlest@gmail.com
}

Received : November 2017

Reviewed : Desember 2017

Accepted : Januari 2018

Published : Januari 2018

\section{ABSTRACT}

The general purpose of this research is to develop a reading supplement book to support the implementation of trifocus method. As for, the specific purpose of this research is to describe the development processes and the qualities of reading supplement book. The qualities of reading supplement book that was developed reviewed based on the product and its use in the classroom. This research included the development research types with combination of qualitative quantitative approach with sequential exploratory model and the model design is an adaption from 4D model. The procedures of development include definition, design, and development stage. The research data are document from development process and data about the quality of supplement book from validator and the the prospective user. Furthermore, collecting data had done through observation technique, questionaries, and test. Analyzing data had done through the combination of qualitative quantitative description technique sequentially. The result of this research showed that the development processes include defining stage is a map of learning needs; draft design stage is draft supplement book; and development stage is final model of reading supplement book. The quality of reading supplement book that was developed assessed from the eligibility of components material, presentation, language, and peripheral exercise. Each component gets percentage 98\%, 91\%, 100\%, dan 98\%. All of that categories get good quality (very suitable). The result of observation towards teachers activity, teachers response, students activity, and students response consecutive in limited trial are $88 \%, 100 \%, 80 \%$, and $93 \%$. At compherensive trial class IV A are $85 \%, 92 \%$, 78\%, dan 94\%, while in class IV B are $89 \%, 96 \%, 81 \%$, dan 94\%. The average of ESR result from limited trial up to compherensive trial consecutive are $102.8 \mathrm{wpm}, 129.3 \mathrm{wpm}$, and 142.7 wpm. There is only compherensive trial class IV B who can reach the ESR ideal, is $140 \mathrm{wpm}$. Although the average of ESR other class can't reach the ESR ideal, however many students who can reach ESR ideal. Based on the research results showed that reading supplement book which developed to support the implementation of trifocus method very suitable to be used.

Keywords: reading supplement book, trifocus method, effective speed reading, elementary school.

\section{ABSTRAK}

Tujuan umum penelitian ini adalah mengembangkan buku suplemen membaca untuk mendukung pelaksanaan metode trifokus. Adapun tujuan khusus penelitian ini adalah mendeskripsikan proses pengembangan dan kualitas buku suplemen membaca. Kualitas buku suplemen membaca yang dikembangkan ditinjau berdasarkan produk dan penggunaannya di kelas. Penelitian ini termasuk jenis penelitian pengembangan dengan pendekatan kombinasi kualitatif kuantitatif model sequential exploratory dan desain model merupakan adaptasi dari model 4D.

Prosedur pengembangan meliputi tahap pendefinisian, perancangan, dan 
pengembangan. Data penelitian berupa dokumen proses pengembangan, dan data kualitas buku suplemen dari validator serta calon pengguna. Selanjutnya, pengumpulan data dilakukan melalui teknik observasi, angket, dan tes. Penganalisisan data dilakukan dengan teknik kombinasi deskripsi kualitatif kuantitatif secara berurutan. Hasil penelitian menunjukkan bahwa proses pengembangan meliputi tahap pendefinisian dengan hasil berupa peta kebutuhan pembelajaran; tahap perancangan dengan hasil draf buku; dan tahap pengembangan dengan hasil berupa model final buku suplemen membaca. Kualitas buku suplemen membaca yang dikembangkan dinilai dari komponen kelayakan materi, penyajian, bahasa, dan pelatihan periferal. Masing-masing komponen mendapatkan persentase 98\%, 91\%, 100\%, dan 98\%. Semua kategori termasuk kategori berkualitas (sangat layak). Pemerolehan hasil observasi terhadap aktivitas guru, respon guru, aktivitas siswa, dan respons siswa berturut-turut pada uji coba terbatas yaitu $88 \%, 100 \%, 80 \%$, dan 93\%. Pada uji coba luas kelas IV A yaitu $85 \%$, 92\%, 78\%, dan 94\%, sedangkan pada kelas IV B yaitu 89\%, 96\%, 81\%, dan 94\%. Rata-rata hasil KEM siswa dari tahap uji coba terbatas, uji coba luas kelas IV A, dan kelas IV B secara berturut-turut yaitu $102.8 \mathrm{kpm}, 129.3 \mathrm{kpm}$, dan $142.7 \mathrm{kpm}$. Hanya kelas uji coba luas IV B saja yang mampu mencapai KEM ideal, yaitu 140 kpm. Meskipun KEM rerata kelas tidak mencapai KEM ideal, namun banyak siswa yang maтри mencapai KEM ideal. Berdasarkan hasil penelitian menunjukkan bahwa buku suplemen membaca untuk mendukung pelaksanaan metode trifokus yang dikembangkan sangat layak untuk digunakan.

Kata Kunci: buku suplemen membaca, metode trifokus, kecepatan efektif membaca, sekolah dasar.

\section{PENDAHULUAN}

Bahasa yang digunakan oleh manusia terbagi menjadi empat keterampilan, yaitu menyimak, berbicara, membaca, dan menulis. Dalam memperoleh keterampilan berbahasa tersebut, manusia biasanya melalui suatu hubungan urutan yang teratur: mula-mula pada masa kanak-kanak mereka belajar menyimak bahasa, kemudian berbicara, sesudah itu mereka belajar membaca dan menulis. Menyimak dan berbicara biasanya dipelajari anak sebelum mereka memasuki usia sekolah dasar. Namun, dalam kurikulum sekolah dasar, keempat keterampilan tersebut dipelajari oleh siswa. Setiap keterampilan tersebut erat sekali berhubungan dengan keterampilan lainnya dengan cara yang beraneka ragam. Keempatnya pada dasarnya merupakan satu kesatuan, merupakan catur tunggal (Tarigan, 1990 :1). Diantara keempat keterampilan tersebut, salah satu keterampilan yang sering menjadi masalah dalam pembelajaran adalah keterampilan membaca.

Pernyataan tersebut sejalan dengan hasil studi yang dilakukan oleh IAEEA (International Association for Evaluation Education Achievement) pada 1992 yang mengungkapkan bahwa kebisaaan membaca siswa Indonesia berada pada peringkat ke-26 dari 27 negara yang diteliti (Suryaman, 2002:94). Lebih lanjut pada tahun 1996 IAEEA kembali melakukan riset yang mengungkapkan bahwa kebiasaan membaca siswa usia 9-14 tahun Indonesia berada pada urutan ke 41 dari 49 negara yang disurvei. Pada tahun 1998-2001, IAEEA kembali melakukan riset, hasilnya adalah kebiasaan membaca siswa Indonesia berada pada urutan terakhir dari 35 negara yang disurvei. Dan pada tahun 2007, IAEEA kembali menginformasikan hasil risetnya tentang minat baca siswa Indonesia yang berada pada posisi yang tidak memuaskan, selevel dengan Negara belahan selatan, bersama dengan Selandia Baru dan Afrika Selatan.

Rendahnya minat dan keterampilan membaca antara lain tampak pada rendahnya kecepatan efektif membaca (KEM) mereka. Hal ini merupakan salah satu indikator bahwa pembelajaran membaca di sekolah belum maksimal. Padahal kita mengetahui bahwa rendahnya kemahiran membaca akan sangat berpengaruh pada kemahiran berbahasa yang lain, yaitu mahir menyimak, mahir berbicara, dan mahir menulis. (Sarwono : 2003).

Untuk itu, pada tahun 2012, dilakukan penelitian mengenai KEM ini. Penelitian ini dilakukan untuk meningkatkan KEM siswa kelas IV SDN 3 Singotrunan Kecamatan Banyuwangi tahun pembelajaran 2013/2014 dengan menggunakan metode trifokus Steve Snyder. Kelebihan dari metode ini adalah penerapannya yang sederhana dan praktis. Metode ini disebut tri fokus karena mengajarkan pada siswa untuk mengembangkan pelatihan periferal siswa dengan latihan "tri fokus". Maksudnya titik konsentrasi pandangan mata terpusat tiga fokus (tiga 
bagian) setiap barisnya. Sebagian dipusatkan di sebelah kiri, sebagian tengah dan sebagian kanan (Sarwono: 2003).

Menurut KBBI, periferal adalah proses melihat tidak mengenai pokoknya. Dalam kaitannya dengan metode trifokus Steve Snyder ini, dapat diartikan bahwa ketika siswa membaca, titik fokus pandangan mata tidak tertuju pada satu kata, melainkan titik fokus tertuju pada satu bagian baik itu yang berupa kelompok kata (frase), klausa atau bagian berdasarkan penjedaan. Dalam membaca, penglihatan periferal yang lebih luas berarti adalah kemampuan untuk menerima informasi lebih banyak dalam satu waktu. Seseorang membaca lebih cepat jika memahami satu frasa dalam sekali pandang. (Sarwono: 2003).

Berdasarkan penelitian yang telah dilakukan, didapatkan hasil bahwa KEM rata-rata siswa kelas IV SDN 3 Singotrunan Banyuwangi meningkat setelah diterapkannya metode trifokus Steve Snyder. Meskipun KEM siswa meningkat pada penelitian tersebut, namun hanya ada 3 dari 16 siswa yang mampu mencapai KEM minimal untuk siswa SD. Selain itu, dalam prosesnya ditemukan fakta bahwa siswa cepat bosan ketika kegiatan latihan periferal sehingga mengharuskan peneliti bermanuver mengganti tiga titik bintang (*) dengan media yang lain.

Melatih keterampilan membaca siswa mulai dari sekolah dasar memang perlu dilakukan oleh guru. Keterampilan membaca sebagai salah satu keterampilan berbahasa tulis yang bersifat reseptif perlu dimiliki siswa SD agar mereka mampu berkomunikasi secara tertulis. Mampu membaca tidak berarti secara otomatis terampil membaca. Akan tetapi terampil membaca tidak mungkin tercapai tanpa memiliki kemampuan membaca. Tanpa memiliki kemampuan membaca yang memadai sejak dini, siswa juga akan mengalami kesulitan belajar di kemudian hari. Kemampuan membaca menjadi dasar utama tidak saja bagi pengajaran bahasa itu sendiri, tetapi juga bagi mata pelajaran lain. Dengan membaca, siswa akan memperoleh pengetahuan yang sangat bermanfaat bagi pertumbuhan dan perkembangan daya nalar, sosial, dan emosionalnya.

Dengan adanya buku suplemen ini, diharapkan siswa mampu meningkatkan kecepatan efektif membaca mereka sehingga mampu meningkatkan kualitas membacanya. Dengan meningkatnya kualitas membaca siswa, maka secara tidak langsung dapat meningkatkan kualitas belajar siswa itu sendiri. Subjek yang digunakan dalam penelitian ini adalah siswa kelas IV SDN 3 Panderejo Tahun pembelajaran 2015/2016 karena berdasarkan studi awal yang dilakukan pada 3-12 Desember 2015 dapat disimpulkan bahwa KEM siswa kelas IV SDN 3 Panderejo Tahun pembelajaran 2015/2016 masih jauh dari KEM ideal (140 kpm). KEM rata-rata siswa kelas IV A adalah 69.44, sedangkan KEM rata-rata siswa kelas IV B hanya sebesar 68.14 yang mana dari kedua kelas tersebut KEM tertinggi hanya sebesar 124.86 yang diraih oleh Yuana Zahra.

Berdasarkan paparan tersebut, maka perlu adanya suatu penelitian untuk mengkaji "Pengembangan Buku Suplemen Membaca untuk Mendukung Pelaksanaan Metode Trifokus guna Meningkatkan Kecepatan Efektif Membaca (KEM) Siswa Kelas IV'. Tujuan dari penelitian ini adalah untuk menghasilkan buku suplemen membaca yang dikembangkan untuk mendukung pelaksanaan metode trifokus yang layak dengan dikaji dari segi produk dan penggunaannya di kelas.

\section{TINJAUAN PUSTAKA}

Nurlaela (2010:9) menyatakan bahwa membaca merupakan suatu proses memahami dan merekonstruksi pesan yang ada dalam bacaan. Pesan atau makna yang terkandung dalam bacaan diperoleh melalui interaksi dinamis antara pengetahuan yang dimiliki pembaca dengan informasi yang tertuang dalam bacaan. Interaksi tersebut yang oleh Crawley dan Mountain (Tarigan, 1990:8) disebut sebagai proses visual dan proses berpikir. Sebagai proses visual, membaca merupakan proses penerjemahan suatu huruf ke dalam kata-kata lisan. Sebagai proses berpikir, membaca mencakup aktivitas pengenalan kata, pemahaman literal, interpretasi, membaca kritis, dan pemahaman kreatif. Menurutnya, membaca pada hakikatnya adalah sesuatu yang melibatkan banyak hal, tidak hanya sekedar melafalkan tulisan, melainkan juga melibatkan aktivitas visual, berpikir, psikolinguistik, dan metakognitif.

Jadi, membaca merupakan suatu proses melisankan dan memahami bacaan dengan tidak hanya sekedar melafalkan tulisan, melainkan juga melibatkan aktivitas visual, berpikir, dan psikolinguistik untuk memperoleh makna atau pesan dari bacaan. Tujuan utama dalam membaca adalah untuk mencari serta memperoleh informasi, mencakup isi dan memahami makna bacaan. Menurut Tarigan (2008:9), tujuan umum membaca adalah (a) membaca untuk memperoleh perincian-perincian atau fakta-fakta; (b) membaca untuk memperoleh ide-ide utama; (c) membaca untuk mengetahui urutan atau susunan, organisasi cerita; (d) membaca untuk menyimpulkan atau membaca inferensi; (e) membaca untuk mengklasifikasikan; (f) membaca untuk mengevaluasi; (g) membaca untuk membandingkan atau mempertentangkan.

Dalam penelitian ini aspek membaca yang ditekankan adalah membaca cepat dan membaca pemahaman. Aspek tersebut perlu ditekankan pada diri siswa karena selain membaca dengan cepat, namun siswa juga harus mampu memahami isi bacaan tersebut. 
Nurhadi (2005:31) mengungkapkan bahwa membaca cepat dan efektif yaitu jenis membaca yang mengutamakan kecepatan dengan tidak meninggalkan pemahaman terhadap aspek bacaannya. Dengan demikian, seseorang dalam membaca tidak hanya kecepatannya yang menjadi patokan, tetapi disertai pemahaman terhadap isi bacaan. Membaca cepat merupakan sistem membaca dengan memperhitungkan waktu baca dan tingkat pemahaman terhadap bahan yang dibacanya. Apabila seseorang dapat membaca dengan waktu yang sedikit dan pemahaman yang tinggi maka orang tersebut dapat dikatakan pembaca cepat. Hal tersebut sejalan dengan pendapat Anderson (1999:2) yang menyatakan bahwa ketercapaian pembaca tidak hanya dilihat dari kemampuan membaca cepatnya saja, namun kemampuan pemahamannya juga, ketika secara khusus pebelajar diajarkan mengenai teknik membaca cepat. Sedangkan pemahaman isi bacaan merupakan tindak lanjut dari proses membaca yang meliputi pengenalan huruf-huruf sebagai bunyi bahasa yang merupakan bagian dari komponen komunikasi tulisan (Tampubolon, 1987:5).

KEM merupakan perpaduan antara kecepatan membaca dan kemampuan memahami isi bacaan. Kecepatan membaca merupakan cerminan dari tolak ukur kemampuan visual, sedangkan kemampuan memahami isi bacaan merupakan cerminan dari kemampuan kognitif pembaca (Hendrasari, 2011:32). Hendrasari (2011:33) berpendapat bahwa untuk menentukan KEM, diperlukan data mengenai skor kecepatan baca dan persentase pemahaman isi bacaan. Cara menghitung skor kecepatan baca adalah dengan cara membagi jumlah kata yang dibaca dengan waktu tempuh baca. Sedangkan untuk menentukan besaranya pemahaman seseorang terhadap isi bahan bacaannya adalah dengan membagi skor bobot bacaaan yang dijawabnya dengan benar dengan skor idela test tersebut.

Metode trifokus Steve Synder adalah sebuah metode membaca yang didesain oleh instruktur baca yang bernama Steve Snyder yang lahir di Los Angeles, Amerika Serikat pada 5 Januari 1952. Steve Snyder pernah mengajarkan para siswa Supercamp di Amerika Serikat untuk mengembangkan kemampuan periferal mereka dengan latihan trifokus (Hendrasari, 2011:45). Dalam latihan trifokus, siswa dianjurkan untuk membagi masing-masing baris menjadi tiga bagian, yaitu sepertiga bagian sebelah kiri, sepertiga bagian tengah, dan sepertiga bagian kanan dengan melihat setiap kelompok kata melalui penglihatan periferal.

Nurhadi (dalam Hendrasari, 2011:43-44), menyatakan bahwa pokok pemikiran yang melandasi metode trifokus ini adalah semakin luas jangkauan mata dalam melihat unit- unit bahasa, semakin cepat pula kemampuan membacanya. Jangkauan mata inilah yang disebut sebagai medan penglihatan (periferal vison). Ketika membaca, mata bergerak mengikuti baris bacaan dari kiri ke kanan dengan gerakan terhenti-henti. Pada saat berhenti itulah mata mengadakan fiksasi (pemusatan perhatian) dan pada saat itulah citra huruf dari bacaan tersebut terbentuk pada fovea (bagian sensitif pada retina) dan informasi dari bacaan diserap. (Tampubolon, 1990:16-17).

DePorter dan Hernacki (2002:271), mengungkapkan pengertian pandangan periferal yang lebih luas, menurutnya, pandangan periferal adalah kemampuan untuk menerima informasi yang lebih banyak dalam satu waktu. Pembaca akan membaca lebih cepat jika pembaca tersebut dapat memahami satu frasa dalam sekali pandang. Premis di balik beberapa pelatihan kecepatan membaca adalah memungkinkan menggunakan pandangan periferal untuk secara bersamaan membaca sebagian besar dari halaman, bahkan mungkin seluruh halaman, bukan satu kata dalam satu waktu (Brozo \& Johns, 1986:243).

Dalam mengembangkan kemampuan periferal siswa dengan menggunakan latihan trifokus, Steve Snyder menciptakan suatu buku. Di dalam buku tersebut tidak terdapat kata-kata, melainkan hanya terdiri dari simbolsimbol. Simbol-simbol tersebut dapat digambarkan sebagai berikut :

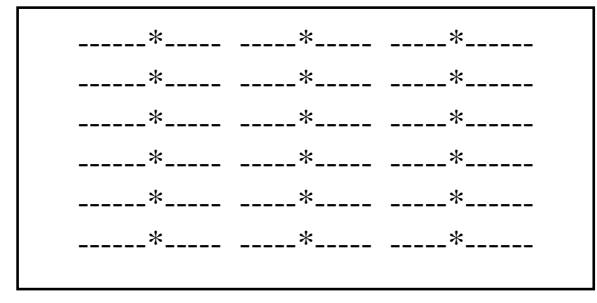

Gambar 1. Simbol Trifokus

Keterangan:

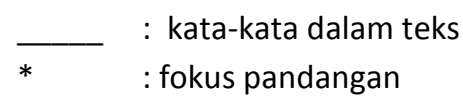

Cara membaca buku ini adalah dengan memusatkan perhatian pada sepertiga bagian sebelah kiri dengan pusat fokus pada bintang, lalu sepertiga bagian sebelah tengah dengan pusat fokus juga pada bintang, dan sepertiga bagian sebelah kanan dengan pusat fokus pada bintang. Hal tersebut dilakukan secara berulang-ulang selama beberapa menit. Bintang-bintang tersebut merupakan fokus pandangan, sedangkan garis-garisnya adalah kata-kata dalam bacaan. Pada saat siswa menggerakkan mata dari bintang satu ke bintang lainnya, siswa diminta berhitung dalam hati secara berirama 1, 2, 3, 1, 2, 3... dan seterusnya secara berulang-ulang. Siswa diarahkan untuk 
menggunakan metode ini untuk membaca bacaan yang sesungguhnya. (Hendrasari, 2011:46).

Permainan edukasi adalah suatu permainan yang mengandung unsur mendidik dan berhubungan langsung dengan pengajaran atau pendidikan. Fungsi permainan edukatif adalah menciptakan suasana belajar yang menyenangkan; membentuk karakter positif anak; merangsang pengembangan daya pikir, cipta, dan bahasa; dan memberikan stimulus dalam pembentukan perilaku dan pengembangan kemampuan dasar.

Permainan sebagai media bagi pembelajaran bagi anak memiliki persyaratan penting, yaitu perlindungan, stimulasi, dan eksplorasi (Craft, 2003:78). Bagi perkembangan dalam tahun-tahun pertama, baik bagi manusia maupun hewan, perlindungan dan stimulasi merupakan syarat multak (Monks, 2002:137). Hal tersebut juga berlaku dalam permainan. Dengan memberikan perlindungan berupa rasa aman, nyaman, dan menyenangkan maka anak akan menikmati permainan tersebut. Dampaknya adalah anak dengan bebas mengeksplor dirinya. Begitu pula dengan stimulus. Stimulus diperlukan untuk mendapatkan respons yang diinginkan. Namun tidak semua stimulus dapat memberikan respons yang sama. Diperlukan stimulusstimulus yang tepat agar didapatkan respons yang diinginkan. Eksplorasi atau penjelajahan menurut Monks (2002:138) merupakan syarat penting dalam permainan.

Buku suplemen adalah buku yang berfungsi sebagai bahan pengayaan bagi anak, baik yang berhubungan dengan pelajaran maupun tidak dan disusun oleh para ahli dalam bidang tersebut dengan cermat dan sistematis berdasarkan perkembangan dan kebutuhan anak yang dilengkapi dengan sarana-sarana pengajaran yang sesuai dan serasi. Penyusunan buku yang berkualitas menurut BSNP (2014), harus memperhatikan empat komponen, yaitu kelayakan materi, kelayakan penyajian, kelayakan kebahasaan, dan kelayakan kegrafikan. Dalam penelitian ini penyusunan buku suplemen yang berkualitas akan mengikuti pedoman dari BSNP yang sudah disesuaikan dengan kebutuhan dalam penyusunan buku suplemen membaca.

Aktivitas siswa diamati untuk mengetahui respons siswa pada saat penggunaan buku suplemen. Aktivitas siswa yang diamati oleh observer mencakup tingkah laku dan sikap siswa selama penggunaan buku suplemen. Aspek-aspek yang diamati dimulai dari kegiatan awal, inti, hingga kegiatan penutup.

Pada kegiatan awal, hal-hal yang diamati, yaitu (1) kesiapan belajar siswa dengan mengucapkan salam, berdoa, dan menjawab presensi yang dibacakan oleh guru; (2) Melakukan tanya jawab dengan guru mengenai KEM; (3) Menyimak penjelasan guru mengenai isi buku suplemen membaca; (4) membaca bagian pendahuluan pada buku suplemen membaca; (5) berdiskusi dengan guru mengenai bagian pendahuluan yang telah dibaca; (6) berdiskusi dengan guru mengenai hal-hal yang dapat menghambat kecepatan membaca.

Pada kegiatan inti, hal-hal yang diamati, yaitu (1) Menyimak penjelasan guru mengenai pandangan periferal; (2) Menyimak penjelasaan guru mengenai isi buku suplemen membaca sesuai dengan subtema yang sedang dipelajari; (3) Berkelompok sesuai dengan arahan guru; (4) Menerima stopwatch dari guru dan mendengarkan guru menjelaskan cara kerja stopwatch; (5) Latihan periferal yang ada di buku suplemen membaca dengan bimbingan guru; (6) Menyimak penjelasan guru mengenai cara mengukur KEM; (6) Melakukan latihan membaca yang sebenarnya dengan arahan dan bimbingan dari guru; (7) Berpartisipasi aktif melalui interaksi dengan guru, teman sebaya, dan buku suplemen membaca; (8) Berpartisipasi aktif melalui interaksi dengan guru, teman sebaya, dan buku suplemen membaca.

Pada kegiatan penutup, hal-hal yang diamati, yaitu (1) Mengisi kolom rekapitulasi KEM dengan bimbingan guru; (2) Merefleksi kegiatan yang telah berlangsung dengan melakukan kegiatan tanya jawab dengan guru; (3) Mengisi kolom refleksi dengan bimbingan guru; (4) Mengumpulkan buku suplemen membaca ke meja guru.

\section{METODE}

Penelitian ini merupakan penelitian pengembangan yang dilaksanakan untuk menghasilkan buku suplemen membaca yang mendukung pelaksanaan metode trifokus. Penelitian dilaksanakan pada siswa kelas IV SDN 3 Panderejo Banyuwangi.

Penelitian ini menggunakan rancangan penelitian pengembangan research and development milik Thiagarajan, Semmel, and Semmel (1974:5) yang disebut 4D (four D model) yang terdiri dari 4 tahapan yaitu: (1) pendefinisian; (2) perancangan; (3) pengembangan; (4) penyebaran. Sugiyono (2012:407) dalam metode penelitian pendidikan mengemukakan metode research and development sebagai metode penelitian yang digunakan untuk menghasilkan produk tertentu, dan menguji keefektifan produk tersebut.

Proses pengembangan perangkat meliputi tahap pendefinisian, perancangan dan pengembangan.

\section{Tahap Pendefinisian}

Tahap pendefinisan merupakan tahapan awal dalam pengembangan 4D yang bertujuan untuk menetapkan kebutuhan-kebutuhan pembelajaran dengan menganalisis tujuan dan batasan materi pokok yang akan dikembangkan. 
Tahap pendefinisian terdiri dari analisis awal-akhir, analisis siswa, analisis konsep, analisis tugas, dan analisis tujuan

Analisis awal-akhir bertujuan untuk mengetahui permasalahan yang dihadapi dalam pembelajaran bahasa Indonesia. Analisis siswa bertujuan untuk mengetahui karakteristik siswa, yaitu KEM awal siswa dan kemampuan perkembangan kognitif siswa. Analisis konsep bertujuan untuk mengidentifikasi konsep utama yang disajikan dalam buku suplemen. Analisis ini yang kemudian menjadi dasar dalam pembuatan buku suplemen.

Analisis tugas merupakan garis besar mengenai tugas yang dilakukan siswa dalam menyelesaikan buku suplemen membaca. Perumusan tujuan menjadi dasar bagi pendidik dalam memilih model pembelajaran, metode pembelajaran, bahan ajar, dan menyusun instrumen evaluasi. Dalam penelitian ini tujuannya adalah untuk mengembangkan buku suplemen membaca untuk mendukung pelaksanaan metode trifokus Steve Snyder guna meningkatkan KEM siswa kelas IV.

\section{Tahap Perancangan}

Pada tahap perancangan, buku suplemen membaca disusun dan ditulis sesuai dengan pemetaan kerangka buku suplemen membaca. Penyusunan buku disesuaikan dengan kurikulum 2013, dalam hal ini dipilih tema 6 Indahnya Negeriku karena guru kelas IV menyarankan tema tersebut untuk dipakai.

Pada tahap ini juga, buku suplemen disusun dengan memperhatikan kelayakan materi, kelayakan penyajian, kelayakan bahasa, dan kelayakan pelatihan periferal. Buku suplemen membaca yang telah ditulis dan disusun merupakan draf I buku suplemen membaca Buku suplemen draf 1 tersebut kemudian divalidasi oleh para validator. Validator merupakan orang yang ahli pada materi pembelajaran, ahli penyajian, ahli bahasa, dan ahli dalam permainan edukatif, yaitu pelatihan periferal.

\section{Tahap Pengembangan}

Penilaian, masukan, dan saran dari validator digunakan untuk merevisi draf 1 buku suplemen membaca. Selanjutnya, buku suplemen tersebut disunting dan diserahkan kembali ke tim validator untuk mendapatkan persetujuan dari tim. Buku suplemen yang telah mendapatkan persetujuan dari validator disebut draf II buku suplemen.

Draf tersebut kemudian diujicobakan pada 10 siswa dan 1 guru kelas IV SDN 3 Singotrunan Banyuwangi tahun pembelajaran 2015/2016, uji coba ini disebut uji coba 1 atau uji coba terbatas. Pada saat uji coba, peneliti mengamati proses pembelajaran dan mencatat aktivitas guru dan siswa. Setelah uji coba terbatas dilakukan, subjek diwawancarai untuk mengetahui tanggapan mereka mengenai pengalamannya menggunakan buku suplemen membaca draf II.

Hasil dari uji coba terbatas tersebut digunakan sebagai masukan dan saran untuk melakukan revisi II sekaligus menjadi draf III, lalu diujicobakan kembali sebagai uji coba II atau uji coba luas. Uji coba luas ini akan diperlakukan pada siswa dan guru kelas IV SDN 3 Panderejo Banyuwangi. Siswa kelas IV SDN 3 Panderejo Banyuwangi terbagi menjadi 2 kelas, yaitu siswa kelas IV A sejumlah 20 kelas dengan 1 guru dan siswa kelas IV B sejumlah 21 siswa dengan 1 guru. Sama halnya dengan uji coba terbatas, dalam uji coba luas ini juga dilakukan pengamatan terhadap subjek dengan mengamati aktivitas siswa ketika menggunakan buku suplemen membaca, mengamati aktivitas guru, dan mengamati kendala-kendala selama uji coba berlangsung. Masukan dan saran dari hasil uji coba luas ini merupakan revisi III. Draf III hasil revisi III divalidasi oleh validator.

Kelayakan dalam penelitian pengembangan ini meliputi hasil validasi buku suplemen membaca, respon pengguna, aktivitas pengguna selama menggunakan buku suplemen membaca, dan hasil KEM siswa. Pengumpulan data dilakukan dengan teknik dokumentasi, validasi, observasi, angket, dan tes. Dokumentasi dilakukan dengan memetakan KI dan KD yang sesuai untuk buku suplemen membaca. Validasi digunakan untuk menilai kualitas buku suplemen membaca yang dilakukan oleh 3 ahli dalam bidang materi, penyajian, bahasa, dan pelatihan periferal dengan menggunakan lembar validasi yang telah disediakan. Observasi dilakukan oleh dua pengamat dengan menggunakan lembar pengamatan yang sama untuk mengamati aktivitas guru dan siswa selama penggunaan buku suplemen membaca di kelas. Mencatat data observasi bukanlah sekedar mencatat, tetapi juga mengadakan pertimbangan kemudian mengadakan penilaian ke dalam suatu skala bertingkat (Arikunto, 2010: 272).

Angket digunakan untuk menggumpulkan data mengenai respon siswa dan guru mengenai materi, bahasa, penyajian, dan pelatihan periferal yang ada dalam buku suplemen membaca. Pemberian tes meliputi pretes (KEM awal siswa) dan posttest. Pretest dilakukan sebelum uji coba terbatas dan uji coba luas dilakukan, tujuannya untuk mengetahui KEM awal dari subjek yang telah ditetapkan. Posttest dilakukan delapan kali, yaitu pada subtema 1 dilakukan sebanyak 4 kali (latihan 1 dan latihan 2 masingmasing dua kali), pada subtema 2 dilakukan sebanyak 4 kali (latihan 1 dan latihan 2 masing-masing dua kali), dan pada subtema 3 dilakukan sebanyak 4 kali (latihan 1 dan latihan 2 masing-masing dua kali), sehingga nanti didapatkan 12 hasil KEM siswa dari 3 subtema tersebut. Siswa dapat 
dikatakan tuntas jika mampu mencapai KEM ideal untuk siswa SD, yaitu $140 \mathrm{kpm}$ (kata per menit).

\section{HASIL DAN PEMBAHASAN}

\section{Proses Pengembangan Buku Suplemen Membaca}

Proses pengembangan buku suplemen membaca dilakukan sekitar bulan Desember 2015 hingga April 2016. Dalam proses pengembangan buku suplemen membaca, penelitian ini menggunakan model 4D yang diadopsi menjadi 3D, sehingga penelitian berhenti pada tahap pengembangan.

Pada tahap pendefinisian terdapat 5 tahapan, yaitu analisis awal-akhir, analisis siswa, analisis konsep, analisis tugas, dan analisis tujuan. Analisis-awal akhir dilakukan dengan mengidentifikasi hasil peneltian tahun 2012 yang menyatakan bahwa KEM rata-rata siswa meningkat tiap siklusnya, namun tidak semuanya mampu mencapai KEM ideal, selain itu siswa cepat bosan ketika berlatih kartu trifokus Steve Synder. Pengidentifikasian dilanjutkan dengan melakukan diskusi dengan guru kelas IV di Banyuwangi yang menyatakan bahwa siswa pada umumnya terlalu menghabiskan banyak waktu ketika mengerjakan tugas menjawab pertanyaan berdasarkan wacana/teks. Beranjak dari hasil identifikasi tersebut kemudian dilakukan studi awal terhadap KEM siswa kelas IV SDN 3 Panderejo Banyuwangi. Hasilnya yaitu KEM siswa rendah, yaitu untuk siswa kelas IV A adalah 69.44 kpm, sedangkan KEM rata-rata siswa kelas IV $\mathrm{B}$ hanya sebesar $68.14 \mathrm{kpm}$.

Berdasarkan hasil analisis siswa kelas IV SDN 3 Panderejo Banyuwangi, ada beberapa hal yang menyebabkan rendahnya KEM siswa, yaitu (a) siswa masih melakukan kebiasaan-kebiasaan yang menghambat kecepatan bacanya; (b) masih ada beberapa siswa yang kurang lancar dalam membaca; (c) kurangnya daya konsentrasi siswa; (d) daya pemahaman siswa terhadap bacaan masih rendah; (e) adanya beberapa troublemaker di dalam kelas yang dapat menyebabkan kegaduhan kelas, akibatnya konsentrasi siswa dapat terganggu; (f) guru belum membiasakan gerakan gemar membaca kepada siswa; (g) selama ini tidak adanya teknik dan perhatian khusus yang digunakan guru untuk meningkatkan kemampuan membaca siswa.

Nuttal (1996:127) mengungkapkan bahwa pembaca yang tidak memahami isi bacaan, atau dalam hal ini Nuttal menyebutnya sebagai "periode buruk bagi pembaca lemah" sering mengalami penurunan dalam nilai membacanya dan mereka tidak menikmati proses membaca tersebut karena membutuhkan bahwak waktu untuk dalam membaca. Kesimpulannya, mereka tidak membaca terlalu banyak, dan tetap melanjutkan periode buruk tersebut. Nuttal menyarankan dengan meningkatkan nilai membacanya, pembaca dapat masuk ke dalam "periode baik bagi pembaca baik". Dengan membaca lebih cepat, pembaca didorong untuk membaca lebih banyak dan dengan membaca lebih banyak maka pemahamannya akan meningkat.

Pendapat Nuttal tersebut sejalan dengan pendapat Stanovich (1986) yang menyarankan bahwa lebih banyak yang siswa baca, maka lebih banyak pula peningkatan kemampuan membacanya. Stanovich menyatakan bahwa pembaca yang kemampuan bacanya baik dan yang kosa katanya juga baik akan membaca lebih banyak, memahami lebih banyak, dan karenanya membacanya lebih baik. pembaca yang kosa katanya tidak memadailah yang membaca dengan pelan dan tanpa menikmatinya, sehingga membacanya lebih sedikit.

Berdasarkan hasil analisis tersebut, dapat disimpulkan bahwa perlunya buku suplemen membaca yang ditujukan untuk meningkatkan kemampuan membaca siswa, khususnya kemampuan membaca cepat dan efektif (KEM) yang dirancang dengan permainan-permainan edukatif yang menyenangkan dan mengasikkan sehingga dapat membuat siswa aktif untuk membaca cepat sekaligus menambah kosa kata siswa sehingga kemampuan pemahamannya juga meningkat, sehingga diharapkan KEM siswa meningkat baik secara individu maupun klasikal.

Konsep utama dalam buku suplemen membaca ini dibagi menjadi 3 bagian, yaitu pelatihan trifokus, yang terdiri dari mengenal kata, mengenal frasa, membaca trifokus, membaca 3 bagian, dan latihan bacaan; pelatihan konsentrasi yang terdiri dari manakah yang berbeda?, puzzle, menjodohkan kata, gambar tersembunyi, ayo berpetualang, mana yang harus dilingkari, dan TTS; dan pelatihan gerak mata, yang terdiri dari mencari perbedaan, scramble, mencari jumlah gambar, temukan aku, dan ayo berhitung!. Konsep tersebut sejalan dengan pendapat Hendrasari (2011:205) bahwa kecepatan baca seseorang dapat dipengaruhi oleh 3 hal, yaitu gerak mata, kebiasaan membaca, dan daya konsentrasi.

Pada pelatihan periferal, khusus pada latihan membaca tiga bagian, latihan dilakukan secara berulang-ulang, yaitu sebanyak tiga kali pengulangan, dan setiap percobaan diukur dengan menggunakan stopwatch untuk mengetahui waktu baca siswa serta peningkatannya. Pengulangan ditujukan agar siswa semakin terbiasa mengaplikasikan simbol-simbol trifokus pada bacaan yang sebenarnya sehingga diharapkan kecepatan membaca siswa semakin meningkat. Hal tersebut sejalan dengan pendapat Samuels bahwa aktivitas membaca berulang digunakan untuk meningkatkan nilai membaca jika siswa membaca teks secara berulang-ulang hingga mereka mencapai kecepatan 
Penurunan tersebut terjadi karena beberapa faktor, yaitu 1) guru tidak memberikan penjelasan lebih lanjut ketika kegiatan membaca pendahuluan; 2) guru kurang luwes ketika membimbing siswa dalam mengerjakan pelatihan di buku suplemen membaca; 3) guru kurang aktif dalam mengarahkan siswa ketika melakukan latihan membaca; 4) guru kurang mampu menguasai kelas dibandingkan kedua guru lainnya; 5) guru kurang menunjukkan sikap terbuka terhadap respons siswa dibandingkan dengan dua guru lainnya.; dan 6) guru kurang aktif dalam menutup pembelajaran. meskipun terjadi penurunan pada kelas IV A, namun ketiganya masuk dalam ketegori sangat aktif.

Respon guru terhadap buku suplemen membaca sangat baik. Hal tersebut terlihat dari hasil angket terhadap respon guru yang dapat dilihat pada grafk 2 berikut ini.

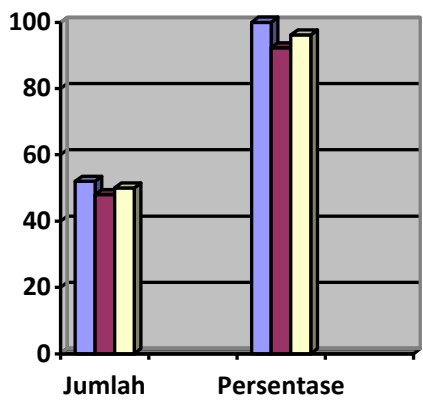

\section{$\square$ Guru UCT $\square$ Guru UCL IV A 口Guru UCL IV B}

Grafik 2. Rekapitulasi Respons Guru Terhadap Buku Suplemen Membaca

Aktivitas siswa dirancang dan disesuaikan dengan aktivitas guru dan berdasarkan sintaks metode trifokus Steve Synder. Aktivitas siswa mulai dari kegiatan awal, inti, dan kegiatan akhir diamati oleh dua pengamat, baik pada saat uji coba terbatas maupun uji coba luas. Hasil pengamatan tersebut kemudian dirata-rata dan disajikan dalam bentuk persentase. Hasil penilaian pengamat dapat dilihat pada Grafik 3.

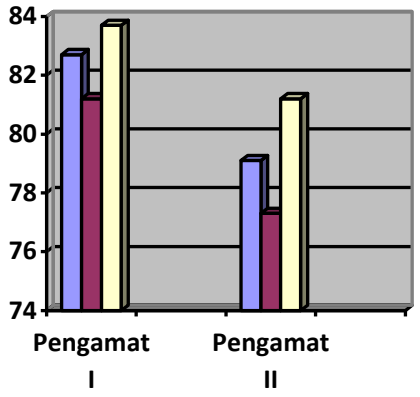

Berdasarkan hasil pengamatan tersebut diketahui bahwa terjadi penurunan pada uji coba luas kelas IV A. Penurunan tersebut terjadi karena beberapa faktor, yaitu 1) ada beberapa siswa yang tidak sungguh-sungguh ketika berlatih, tidak tertib, tidak tenang, dan mengganggu teman lainnya; 2) ada beberapa siswa yang tidak aktif dalam kegiatan diskusi; 3) ada beberapa siswa yang tidak menyimak dengan serius instruksi dari guru, membuat kegaduhan selama aktivitas latihan berlangsung, berlatih dengan tidak sungguh-sungguh setiap latihan, dan melakukan aktivitas lain (selain yang berhubungan dengan pembelajaran) ketika mengerjakan pelatihan; 4) ada beberapa siswa yang tidak menyimak arahan guru, berbuat gaduh ketika latihan membaca, mengganggu teman lainnya ketika kegiatan membaca berlangsung, mengobrol dengan teman lainnya ketika kegiatan membaca berlangsung, dan tidak mampu bekerja sama dengan kelompoknya ketika kegiatan membaca; 5) ada beberapa siswa yang kurang antusias dan ceria dalam belajar. Meskipun terjadi penurunan pada kelas IV A, namun ketiga kelas tersebut masuk dalam kategori aktif.

Respon siswa terhadap buku suplemen membaca juga tergolong kategori sangat baik. Hal tersebut terlihat dari hasil angket terhadap respon siswa yang dapat dilihat pada grafik 4.
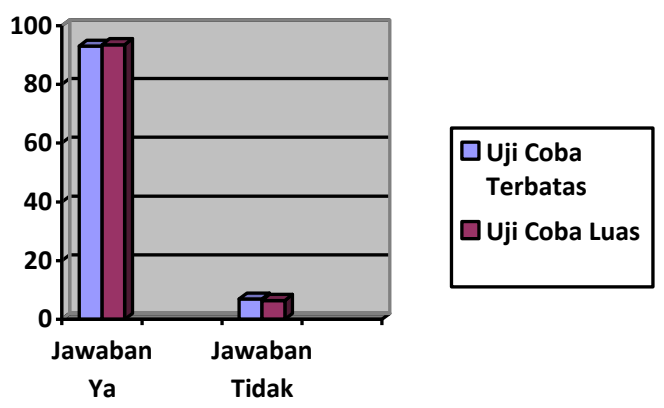

Grafik 4. Respon Siswa Terhadap Buku Suplemen Membaca

Selain aktivitas dan respon siswa dan guru, kualitas buku suplemen juga dilihat dari hasil belajar siswa, yaitu KEM siswa. Hasil KEM yang diperoleh siswa selama penggunaan buku suplemen membaca mengalami peningkatan. Peningkatan tersebut dapat dilihat pada grafik 5 berikut.
Grafik 3. Rekapitulasi Hasil Pengamatan Aktivitas Siswa Selama Penggunaan Buku Suplemen Membaca 


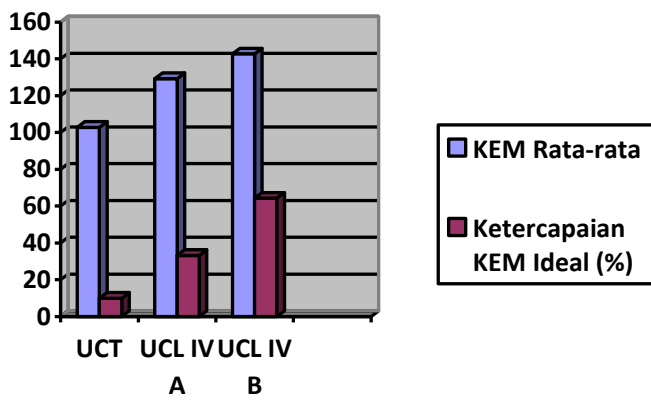

Grafik 5. Rekapitulasi Hasil KEM Siswa

Berdasarkan hasil analisis, diketahui bahwa KEM rerata kelas uji coba terbatas sebesar $35.3 \mathrm{kpm}$, pada subtema 1 meningkat menjadi $80.6 \mathrm{kpm}$, pada subtema 2 sebesar $128.1 \mathrm{kpm}$, dan pada subtema 3 sebesar $167.3 \mathrm{kpm}$. Jika dirata-rata secara keseluruhan KEM rerata kelas uji coba terbatas sebesar $102.8 \mathrm{kpm}$.

KEM tersebut belum mampu memenuhi KEM standar. Hal tersebut dikarenakan beberapa faktor, yaitu 1) banyak siswa yang masih belum hafal perkalian, sehingga membutuhkan waktu yang lama untuk melakukan operasi hitung pembagian (penghitungan KEM); 2) pembelajaran dilakukan pada siang hari sehingga siswa kurang berkonsentrasi dan mudah lelah; 3) pada pelatihan puzzle dan TTS membutuhkan waktu yang lama karena siswa sendiri yang harus memotong bahan puzzle. Meskipun KEM tersebut belum memenuhi standar KEM ideal, namun hampir seluruh siswa mampu mencapai KEM ideal. Dari 10 siswa, hanya 1 siswa saja yang tidak mampu mencapai KEM ideal. Selain itu, pada uji coba terbatas ini KEM rerata siswa naik secara konstan.

Sama halnya pada uji coba terbatas, pada uji coba luas kelas $\mathrm{IV}^{\mathrm{A}}$ ini hanya 1 dari 12 siswa yang tidak mampu mencapai KEM ideal. Selain itu, pada uji luas kelas IV ${ }^{\mathrm{A}}$ ini ada 1 siswa yang peningkatan KEM-nya tidak konstan. Namun, KEM rerata total pada kelas ini lebih besar dibandingkan dengan uji coba terbatas, yaitu sebesar 129.3 kpm. Angka tersebut masih belum memenuhi KEM ideal untuk siswa SD, yaitu sebesar $140 \mathrm{kpm}$. Hal tersebut dikarenakan guru kurang mampu mengontrol troublemaker sehingga mengganggu siswa yang lain.

Uji coba yang mampu mencapai KEM rerata total ideal, yaitu pada uji coba luas kelas $\mathrm{IV}^{\mathrm{B}}$, yaitu sebesar 142.7 kpm. Selain itu, pada kelas ini seluruh siswanya mampu mencapai KEM yang diharapkan. Hanpir seluruh siswa mampu meningkatkan KEM-nya secara konstan, hanya 1 siswa saja yang tidak mampu meningkatkannya secara konstan. Hal tersebut dikarenakan siswa tersebut merupakan siswa troublemaker yang hiperaktif, meskipun guru cukup mampu mengaturnya agar tidak mengganggu siswa lainnya, namun siswa tersebut tidak mampu berkonsentrasi dengan baik.

Berdasarkan analisis data hasil KEM siswa didapatkan kesimpulan bahwa buku suplemen membaca ini dapat meningkatkan KEM siswa. Perubahan tersebut sesuai dengan teori belajar yang dikemukakan oleh Suyono dan Hariyono (2011: 9) bahwa belajar adalah suatu aktivitas atau proses untuk memperoleh pengetahuan, meningkatkan keterampilan, memperbaiki perilaku, sikap, dan mengkokohkan kepribadian.

\section{PENUTUP}

\section{Simpulan}

Berdasarkan diskusi hasil penelitian yang telah dipaparkan, dapat disimpulkan bahwa buku suplemen membaca yang dikembangkan untuk mendukung pelaksanaan metode trifokus layak untuk melatihkan kecepatan efektif membaca siswa kelas IV sekolah dasar karena telah memenuhi kriteria kelayakan dari segi produk dan penggunaannya di kelas sehingga buku suplemen dapat dipergunakan.

\section{Saran}

Berdasarkan diskusi dan temuan selama penelitian, disarankan dalam penerapan buku suplemen membaca yang dikembangkan untuk mendukung pelaksanaan metode trifokus, guru benar-benar memahami isi buku suplemen dan langkah pembelajaran yang harus dilakukan agar diperoleh hasil KEM yang maksimal.

\section{DAFTAR PUSTAKA}

Anderson, Neil J. 1999. Improving Reading Speed: Activities for The Classroom. English Teaching Forum. April - Juni, pp. 1-5

Arikunto, Suharsimi. 2010. Prosedur Penelitian Suatu Pendekatan Praktik. Jakarta: Rineka Cipta

Brozo, W. G., \& Johns, J. L. 1986. A Content Analysis of 40 Speed Reading Books. Journal of Reading, 30, p. $242-247$

Craft, Anna. 2003. Membangun Kreativitas Anak. Penterjemah M. Chairul Anam. Jakarta: Inisiasi Press

De Porter, Bobbi \& Mike Hernacki. 2002. Quantum Learning: Membiasakan Belajar Nyaman dan Menyenangkan. Jakarta: Mizan Media Utama

Hendrasari, Y. S.. 2011. Peningkatan Kecepatan Efektif Membaca (KEM) Teks Nonsastra dengan Teknik TriFokus Steve Snyder dan Media Video Membaca Cepat Karya Muhammad Noer Pada Siswa Kelas VIII G SMP Negeri 1 Sleman. 
http://eprints.uny.ac.id/4325/1/YURNA\%20SH.pdfRiv

a. [25 November 2015]

Nurhadi. 2005. Membaca Cepat dan Efektif. Bandung: Sinar Baru

Nurlaela, Luthfiyah. 2010. Model Pembelajaran, Gaya Belajar, Kemampuan Membaca, dan Hasil Belajar. Surabaya: Unesa University Press

Nuttal, C. 1996. Teaching Reading Skills in a Forgein Language. Oxford: Heinmann

Samuels, S. 1979. The Method of Repeated Readings. The Reading Teacher, 32 (4), pp 403 - 408

Sarwono, M.. 2003. Peningkatan Kecepatan Efektif Membaca (KEM) dengan Teknik Trifokus Steve Synder. http://pakguruonline.pendidikan.net. Diakses pada 25 November 2015

Stanovich, K. 1986. Mathew Effect in Reading: Some Consequences of Indovodual Differences in The Acquisition of Literacy. Reading Research Quaterly, 21, pp. $360-407$

Suryaman, Maman. 2002. Kemampuan Baca SLTP di Kabupaten dan Kota Bandung. Litera Volume 1 No 2, Juli. Halaman 93-102

Suyono dan Hariyanto. 2011. Belajar dan Pembelajaran. Bandung: PT Remaja Rosdakarya

Tarigan, Henry Guntur. 1990. Membaca sebagai Suatu Keterampilan Berbahasa. Bandung : Angkasa 2008. Membaca: Sebagai Suatu Keterampilan Berbahasa. Bandung: Angkasa

Tampubolon. 1987. Kemampuan Membaca: Teknik Membaca Efektif dan Efesien. Bandung: Angkasa

Thiagarajan, S. Semmel, D.S. \& Semmel, M. I. 1974. Instructional Development for Training Teachers of Exceptional Children. Indiana: Indiana University Bloomington. 